\title{
Article
}

\section{Introduction to the special issue on honour-based abuse, violence and killings}

Khan, Roxanne

Available at http://clok.uclan.ac.uk/23056/

Khan, Roxanne ORCID: 0000-0002-3485-2450 (2018) Introduction to the special issue on honour-based abuse, violence and killings. Journal of Aggression, Conflict and Peace Research, 10 (4). pp. 237-238. ISSN 17596599

It is advisable to refer to the publisher's version if you intend to cite from the work. http://dx.doi.org/10.1108/AACPR-06-2018-0362

For more information about UCLan's research in this area go to http://www.uclan.ac.uk/researchgroups/ and search for <name of research Group>.

For information about Research generally at UCLan please go to http://www.uclan.ac.uk/research/

All outputs in CLoK are protected by Intellectual Property Rights law, including Copyright law. Copyright, IPR and Moral Rights for the works on this site are retained by the individual authors and/or other copyright owners. Terms and conditions for use of this material are defined in the policies page.

\section{CLoK}

Central Lancashire online Knowledge www.clok.uclan.ac.uk

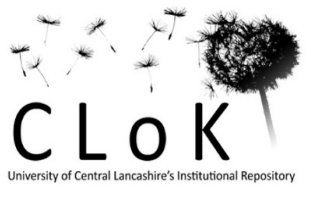




\section{Introduction to the Special Issue on Honour Based Abuse,} Violence, and Killings.

\begin{tabular}{|r|l|}
\hline Journal: & Journal of Aggression, Conflict and Peace Research \\
\hline Manuscript ID & JACPR-06-2018-0362 \\
\hline Manuscript Type: & Editorial \\
\hline
\end{tabular}

SCHOLARONE $^{\text {in }}$

Manuscripts 


\section{Guest Editorial}

\section{Introduction to the Special Issue on Honour Based Abuse, Violence, and Killings.}

In acknowledgement of the many efforts made to increase our knowledge on honour crimes, the Journal of Aggression, Conflict, and Peace Research (JACPR) is publishing this special edition on Honour Based Abuse, Violence, and Killings.

In the past two decades, a series of high-profile honour killings has raised awareness of an archaic form of abuse occurring not only behind closed doors, but within closed community walls. Despite their historic and ubiquitous occurrence, honour crimes are now more commonly associated with Middle Eastern or South Asian families living in patriarchal collectivist cultures in countries of origin and diasporic communities worldwide. Honour abuse victims - mostly young females - are reportedly controlled, coerced, forced into marriage, humiliated, beaten, tortured, and even murdered by close relatives in the name of so-called 'honour'. This cultural conceptualisation of honour is both powerful and pervasive. Built upon rigid gender-based hierarchies, it is often used to promote and excuse aggressive hypermasculinity and female dehumanisation. It is in this context that an influential first wave of scholarly research has been articulately produced, dismantling honour based abuse using a gendered lens.

Due to their focus on peripheral topics, this collection of papers perhaps reflects the beginning of a second wave of research, adding new dimensions to our empirical knowledge on honour abuse. These papers, submitted from across Asia, Europe, and North America, reflect two broad themes. Firstly, topics that relate to obstacles in formal help-seeking responses include police treatment of vulnerable 'at risk' adults (Aplin, 2018), victims' concerns about reporting to police (Gangoli et al., 2018), and professional management of collective violence (Lidman \& Hong, 2018). Secondly, novel issues that explicitly broaden current knowledge include comparisons with anti-LGBTQ homicides (Henry et al., 2018), perceptions of abuse from multiple nations (Lowe at al., 2018), and female perpetrators (Bates, 2018). As a collection, these papers indicate avenues for future research. Therefore, I would like to use them as a starting point to offer suggestions for how research in this area may best advance.

As a psychologist, I am eager for empirical research to use established, social psychological theories to explain honour-based abuse. Since first proposed by Nesbitt and Cohen (1996), a plethora of research has examined males' readiness to aggress in "cultures of 
honor", yet reference to this is uncommon despite its clear relevance. Psychologicallyoriented motivational models of honour violence (based on Theory of Planned Behavior, e.g., Roberts, 2014) are also likely to be valuable.

Applying alternate perspectives permits a more holistic examination of questions such as, why do some males in collectivistic honour cultures use or justify extreme honour-based violence or coercion against female kin, while others do not? It would also be useful if empirical attention focused not only on why some people aggress, but the nuances in their attitudes and motivations for doing so. This would help us understand why some males oppose or desist honour-based abuse, despite the powerful force of social expectations. Other questions include, why do some females endorse or perpetrate honour abuse against other females in collectivistic cultures of honour? This topic is often overlooked even though it conflicts with traditional gender role expectations of women as non-aggressive and protective of close kin. In the broader aggression literature, contemporary knowledge on female abusers indicates that honour abuse by women will not be satisfactorily explained by forcefully extrapolating from research on male aggression. This view is amplified by recent empirical research that challenges traditional views with reports of mothers, in particular, using extreme methods of honour abuse, often against their own daughters, that cannot always be explained by male coercion (Aplin, 2017; Bates, 2018; Khan, 2018).

To aid the myriad challenges faced by safeguarding practitioners and emergency services, I am also keen for evidence-based research to bridge the gap between knowledge and practice. For perpetrators, effective violence management ought to be both culturallyaware and based on validated methods. A good example is the PATRIARCH (Belfrage et al, 2012), developed specifically to guide professionals on the assessment of honour-based crime. Empirically-rooted psychological theories, currently used in interventions to promote prosocial attitudes and victim empathy in comparable violent offender groups, provides a framework for designing effective perpetrator programmes. If the goal of our collective efforts is a change in how 'honour' is misconstrued (e.g., "Sharaf Heroes" programme, Rexvid \& Schlytter, 2012), then adopting robust models of attitudinal change seem a good place to start.

My final words are of gratitude to those involved in the production of this special issue. I thank all authors who submitted their work to $J A C P R$, the expert reviewers for their meticulous and thoughtful comments, the publishing team for ensuring a quality and timely publication, and finally, Editor in Chief, Jane Ireland, for the opportunity to act as Guest Editor on what I believe is a laudable first special edition on this topic. 


\section{References}

Aplin, R. (2017). 'Exploring the role of mothers in 'honour' based abuse perpetration and the impact on the policing response", Women's Studies International Forum (Vol. 60, pp. 1-10). Pergamon.

Belfrage, H., Strand, S., Ekman, L. and Hasselborg, A. (2012). “Assessing risk of patriarchal violence with honour as a motive: six years' experience using the PATRIARCH checklist", International Journal of Police PATRIARCH checklist", International Journal of Police Science \& Management (Vol. 14 No. 1, pp. 20-9).

Khan, R. (2018). “Attitudes towards 'honor' violence and killings in collectivist cultures: Gender differences in Middle Eastern, North African, South Asian (MENASA) and Turkish populations", In Ireland, J. L., Birch, P. \& Ireland, C. A. (Eds.), International Handbook in Aggression: Current Issues and Perspectives, Chapter 6, (pp. 216-226). London: Routledge.

Nisbett, R.E., \& Cohen, D. (1996). "Culture of honor: The psychology of violence in the South”. Boulder, CO: Westview Press.

Rexvid, D., \& Schlytter, A. (2012). "Heroes, hymen and honour: A study of the character of attitude change among male youth with their roots in an honour-based context", Review of European Studies (Vol. 4 No.2, pp. 22-32).

Roberts, K. (2014), “Towards a psychologically oriented motivational model of honour-based violence", in Gill, A.K., Strange, C. and Roberts, K. (Eds), Honour Killing and Violence: Theory, Policy and Practice, (pp. 69-88). New York: Palgrave Macmillan. 